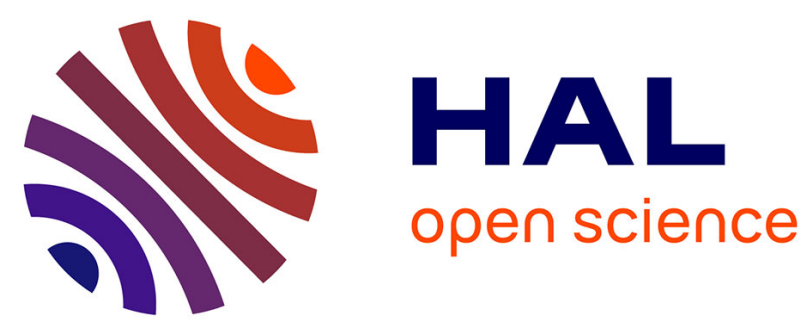

\title{
Estimating changes in effective values of surface detention, depression storage and friction factor at the interrill scale, using a cheap and fast method to mold the soil surface micro-topography
}

Michael Antoine, Claire Chalon, Frédéric Darboux, Mathieu Javaux, Charles Bielders

\section{To cite this version:}

Michael Antoine, Claire Chalon, Frédéric Darboux, Mathieu Javaux, Charles Bielders. Estimating changes in effective values of surface detention, depression storage and friction factor at the interrill scale, using a cheap and fast method to mold the soil surface micro-topography. CATENA, 2012, 91, pp.10-20. 10.1016/j.catena.2010.11.003 . hal-02646103

\section{HAL Id: hal-02646103 \\ https://hal.inrae.fr/hal-02646103}

Submitted on 29 May 2020

HAL is a multi-disciplinary open access archive for the deposit and dissemination of scientific research documents, whether they are published or not. The documents may come from teaching and research institutions in France or abroad, or from public or private research centers.
L'archive ouverte pluridisciplinaire HAL, est destinée au dépôt et à la diffusion de documents scientifiques de niveau recherche, publiés ou non, émanant des établissements d'enseignement et de recherche français ou étrangers, des laboratoires publics ou privés. 
Version définitive du manuscrit publié dans / Final version of the manuscript published in :

Catena, 91, 10-20

\title{
Estimating changes in interill surface detention and depression storage using a cheap and fast method to mold the soil surface roughness.
}

\author{
Michaël ANTOINE ${ }^{1}$, Claire CHALON ${ }^{1}$, Frédéric DARBOUX ${ }^{2}$, Mathieu JAVAUX ${ }^{1}$, and \\ Charles BIELDERS ${ }^{1}$ \\ ${ }^{1}$ Department of environmental sciences and land use planning (MILA), Université \\ catholique de Louvain, Croix du Sud 2, bte 2, 1348 Louvain-la-Neuve, Belgium. \\ michael.antoine@uclouvain.be \\ ${ }^{2}$ INRA, UR 0272 Science du sol, Centre de recherche d'Orléans, CS 40001, F-45075 \\ Orléans Cedex 2, France. Frederic.Darboux@orleans.inra.fr
}

October 2009, version 2

\begin{abstract}
Surface detention and depression storage constitute the two conceptual storages of water at the soil surface and depend on the spatial configuration of the micro-topography. To be able to measure directly those storages and investigate how they develop with time and precipitation, it is necessary to isolate the impact of the micro-topography from the infiltration. Therefore we developed a fast and cheap in-situ molding method $\left(+/-85 € / \mathrm{m}^{2}\right)$ that combines alginate, plaster and lacquer. It allows to create stable and impermeable artificial micro-topographies that reproduce real fields situations and that can be submitted to various laboratory runoff simulations. Both the surface of a specific soil and its artificial reproduction have been measured with a laser scanner in order to assess the quality of the molding method. This method is shown to be precise with a standard deviation of 0.55 millimeter, which is also the spatial resolution of the laser scanner method.

This novel molding method was applied to get ten footprints of the micro-topography of a loamy bare soil, at different levels of cumulative rainfall erosivity value, starting with a tilled soil, and letting it evolve with natural rain events. We studied the evolution of depression storage and surface detention and related the hydraulic properties of the micro-topography with the accumulation of rain erosivity. We observed a general decrease of both storages and proposed a simple model to compute the surface detention as a function of the discharge per unit width and cumulative rain erosivity value.
\end{abstract}

\section{Introduction}

Depending on the micro-topographical spatial configuration, the overland flow may conceptually be distributed among two compartments: the depression storage and the surface detention [Stammers and Ayers, 1957]. The depression storage (also called surface retention or dead storage) is the amount of water stored in surface pits and depressions. This water will subsequently infiltrate or evaporate. On the contrary, the surface detention corresponds to the water storage in excess of depression storage. It is due to the presence of flowing water and depends on the discharge itself. This amount of water will deplete as discharge decreases. Those two compartments are explicitly expressed, for a determined area, in the storage equation [Stammers and Ayers, 1957]: 
Version définitive du manuscrit publié dans / Final version of the manuscript published in :

Catena, 91, 10-20

$$
P-Q=D_{s}+S_{d}+F
$$

where $P$ is the rainfall mass [kg], $Q$ is the runoff mass $[\mathrm{kg}], D_{s}$ is the depression storage $[\mathrm{kg}], S_{d}$ is the surface detention $[\mathrm{kg}]$ and $F$ is the infiltration mass $[\mathrm{kg}]$. Evapo-transpiration is neglected in this equation. Therefore, it is only applicable during the rain event. The variables of the storage equation can also be expressed in terms of volume $\left[\mathrm{m}^{3}\right]$ or water depth $[\mathrm{m}]$ if divided by the soil surface area $\left[\mathrm{m}^{2}\right]$.

The soil properties that govern the retention and detention of overland flow are variable in space, but also evolve in time [Chahinian et al., 2006] with the history of flows through the system. Erosion-deposition processes resulting from those flows will modify the surface microtopography, breaking down soil aggregates [Paz-Ferreiro et al., 2008], filling depressions [Guzha, 2004], incising channels at the outlet of puddles [Darboux et al., 2002] and favoring the development of preferential eroded pathways [Favis-Mortlock, 1998]. At the interill, rain locally rearranges soil particles with the splashing process and the flattening of soil aggregates [Guzha, 2004]. The erosive impact of the rain is classically summarized by the rain erosivity, or R factor of the Revised Universal Soil Loss Equation [Verstraeten et al., 2006], which can be established based on rain intensity measurements. If a clear link can be identified between the rain erosivity and properties that determine depression storage and surface detention, then the $\mathrm{R}$ factor could help for the modeling of runoff on soil surfaces that evolve with the accumulation of rain events.

On small experimental plots, $P$ and $Q$ are directly measurable, whereas $F$ is often modeled based on additional experiments. On the contrary, $D_{s}$ and $S_{d}$ are not easily measured due to the infiltration that occurs simultaneously. Therefore, $D_{s}$ and $S_{d}$ are usually evaluated indirectly.

$D_{s}$ can be evaluated numerically with a filling algorithm [Planchon and Darboux, 2002] if a detailed survey of micro-topography has been made. On the side, attempts have been made to find simpler estimations of the maximum value of $D_{s}$ that are based on direct measurements of roughness indicators in the field. In a comparative study of different roughness indicators, Kamphorst et al. [2000b] found that random roughness, combined with the slope, could furnish the best estimation of maximum $D_{s}$ (within $3 \mathrm{~mm}$ ). Take note that random roughness is classically determined at the meter scale [Jester and Klik, 2005; Elbasit et al., 2009], which also corresponds to elementary grid size in classical hillslope runoff and erosion models. We will therefore adopt the meter scale in our experiments.

$S_{d}$ depends on the integration of the continuity equation and will evolve locally to reach a dynamic equilibrium between water reaching (by runon and precipitation) the specific location for which $S_{d}$ is computed and water leaving that location (by runoff and infiltration). If all the microtopography is known, $S_{d}$ can be evaluated by a detailed hydraulic modeling [Antoine et al., 2009]. As mentioned by Dunkerley [2003], local obstacles in the way of the flow can generate small backwater effects that significantly contribute to $S_{d}$. Although, interill flows are usually modeled as uniform and broad sheet flows [Smith et al., 2007], where the effect of the micro-topography is incorporated in a friction or resistance factor. The Darcy-Weisbach friction factor $\lambda$ is often used to model resistance, and it can be converted to Chézy or Manning friction parameters [Smith et al., 2007]. $\lambda$ has been linked, among other, to random roughness [Gilley and Finkner, 1991; Smart et al., 2002], relative roughness parameterized with grain size distribution [Henderson, 1966] and inundation ratio [Lawrence, 1997]. A commonly used alternative is to calibrate that factor, based on the comparison of observed and modeled hydrographs [Esteves et al., 2000; Tatard et al., 2008].

However, all these indirect evaluations may be erroneous due to spatial resolution limitations in the digital elevation models [Abedini et al., 2006; Martin et al., 2008], overhang problems [Kamphorst and Duval, 2001], or modeling simplifications and numerical approximations. When correlations with topographic indicators are used, the spatial configuration of roughness is often ignored although being determinant [Dunkerley, 2003; Antoine et al., 2009]. Therefore, direct 
Version définitive du manuscrit publié dans / Final version of the manuscript published in :

Catena, 91, 10-20

measurements techniques for real field micro-topographies need to be developed further. To be able to measure $D_{s}$ and $S_{d}$ directly, it is necessary to work with impermeable soil surfaces. Two options are possible, either by impregnating the soil in-situ with a liquid that solidifies and waterproofs the soil surface, or by making an impermeable reproduction with molding methods. Gayle and Skaggs [1978] chose the first option and impregnated the soil surface with resin, but this technique required dry soils. In addition, problems of reliability appeared such as cracks formation as water was poured onto the impregnated surface. Takken and Govers [2000] sprayed a mixture of wood glue (PVA) and water to fix the soil surface, refilled the cracks that appeared with the previous mixture and soil and, finally, sprayed a waterproofer for tent on the whole surface. The second option, i.e. the molding method, has been used by Garcia-Sanchez [1997], Kamphorst and Duval [2001] and Roche et al. [2007]. Garcia-Sanchez [1997] used a plaster to make the mold and an elastomer for the casting, but problems were encountered during the removal of the cast from the mold. Kamphorst and Duval [2001] improved the technique by using an elastic silicone elastomer for the mold and a polyester resin for the casting. This solution produced robust and impermeable copies of the micro-topography and details less than $0.1 \mathrm{~mm}$ width were correctly reproduced. The first drawback of the technique is the time required to mold the surface $(24 \mathrm{~h})$, and the fact that the silicone partially infiltrates into the soil, which subsequently requires a manual removal of some silicone features corresponding to pore space rather than depressions. The second drawback is the price of materials used $\left(+/-600 € / \mathrm{m}^{2}\right)$. This can limit to some extent the number of repetitions and the size of the micro-topography samples investigated during a study.

Our objective is to study the impact of the rain erosivity on $D_{s}$ and $S_{d}$ and to demonstrate the potential of the molds for determining directly those values in real field conditions. These measurements could provide realistic values of $D_{s}$ and $S_{d}$ to be introduced in hillslope models of runoff and give an insight into the non stationarity of those properties in time.

As numerous molds will have to be created, we developed a new methodology to produce impermeable surfaces at a lower cost and in a less time-consuming manner than actual molding methods of soil surface. Different combinations of cheap materials were tested and the most convenient was selected. The quality of the micro-topographical reproduction was assessed through a comparison of real and cast micro-topographies analyzed by laser scanning.

\section{Materials and Methods}

\subsection{Development of the molding method}

Based on discussions with people using molding methods for particular applications (dentists, podiatric physicians, criminal squad and model makers), we identified several cheap materials and fast procedures either to fix and waterproof the soil surface or to mold it. To assess the feasibility of those procedures to mold soil surfaces in real field conditions, we firstly tested them in the laboratory on wet soil samples. For the waterproofing of the soil surface, the tested materials were: a water-repellent additive for concrete, a liquid latex, some color spray painting and an acrylic polyurethane lacquer. But none of these products gave reliable results, due either to a bad waterproofing or to a modification of the micro-topography. We concluded that in situ waterproofing of soil was difficult and we focused our trials on molding methods. We tested the following materials for the mold: agar jelly, paraffin, plaster, alginate and cement for wet environment with a fast setting time. Alginate gave the best results and was easily cleaned of loose soil. Finally, we tested the following materials for the cast: cement, latex, alginate and plaster. The best association was alginate (alginate aroma fine ${ }^{\circledR}$ DF III normal) for the mold and plaster (molda ${ }^{\circledR}$ III normal) for the cast. The plaster cast was subsequently coated with a thin layer of lacquer (French Polish of Ciranova ${ }^{\circledR}$ ) to render it almost impermeable and non-erodible without altering 
Version définitive du manuscrit publié dans / Final version of the manuscript published in :

Catena, 91, 10-20

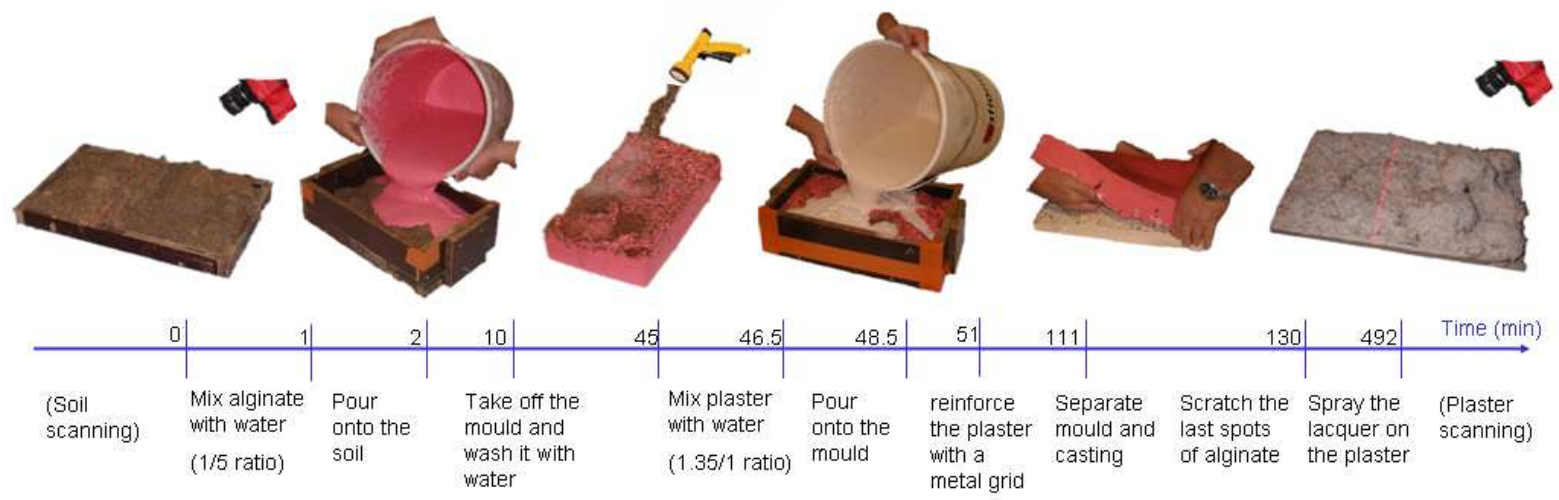

Figure 1: Procedure to cast the soil surface roughness.

the micro-topography.

Alginate is a polysaccharide extracted from brown algae and constitutes the raw material for dental molding. This flexible and robust material provides precise results. Figure 1 illustrates the molding procedure. The alginate powder is mixed with water (our best test was made with a ratio of $1 \mathrm{~kg}$ alginate powder $/ 5 \mathrm{~kg}$ water) and agitated during one minute, avoiding the formation of too many bubbles. Then it is poured onto the soil surface previously delimited by a formwork. The alginate polymerizes in less than 2 minutes, even quicker under hot conditions. After 10 minutes, the mold can be manipulated and removed from the soil surface. It is washed with water to get rid of the loose soil particles or aggregates that can stick to the alginate mold. Take note that the alginate mold shrinks when it dries and needs thus to be kept in a humid environment (e.g. by keeping it in a tightly-closed plastic bag). The plaster is mixed with water (our best test was made with a ratio of $1.35 \mathrm{~kg}$ plaster/ $1 \mathrm{~kg}$ water) and agitated during one and a half minute. Then it is poured onto the alginate mold enclosed on its sides by the previous formwork. We submerge a metal grid in the plaster to reinforce it. The plaster will begin to harden after 10 minutes. After 2 hours, the plaster is separated from the alginate. Six hours later, the lacquer is sprayed onto the plaster that have been cleaned of the last spots of alginate. The entire procedure costs about $85 €$ per square meter (alginate: $14 € / \mathrm{kg} \mathrm{x} 4 \mathrm{~kg} / \mathrm{m}^{2}$, plaster: $0.4 € / \mathrm{kg} \mathrm{x} 30 \mathrm{~kg} / \mathrm{m}^{2}$; lacquer: $16 € /$ liter $\mathrm{x} 1 \mathrm{liter} / \mathrm{m}^{2}$ ), which is much cheaper than traditional silicone molds.

\subsection{Validation of the molding method}

In order to asses the quality (in term of good precision in the reproduction of the micro-topography) of the selected molding method, we measured the elevation of original micro-topographies as well as their reproductions with a laser scanner [Darboux and Huang, 2003]. The micro-topographies considered in the validation procedure are: a 2D-profile of a flat PVC surface with three peaks, a 2D-profile of a patterned PVC surface and a 3D-surface of a real rough and wet soil sample $\left(0.07 \mathrm{~m}^{2}\right)$. The laser scanner consists of two laser diodes that project vertically on the surface a narrow line of intense light. The distortion of this line by the micro-topography, when viewed from an oblique angle, is captured by a camera. Using a calibration procedure, the image of the distorted line is back-transformed to an elevation profile. To obtain the entire micro-topography, the line is scanned across the surface with an increment of $0.5 \mathrm{~mm}$, which determines the spatial $\mathrm{x}-\mathrm{y}$ resolution. The $\mathrm{z}$ resolution is also $0.5 \mathrm{~mm}$ which results from the distance between the mold and the camera as well as the laser beam thickness. Shading effects can appear when the micro-topography itself hides some portions of the line, which will result in an incomplete digital elevation model. Therefore, two scans were made, with the camera on one or the other side of the 
Version définitive du manuscrit publié dans / Final version of the manuscript published in :

Catena, 91, 10-20

line, so that the shadow effects does not always occur on the same side of the protruding objects. An image adjustment process (namely an image registration) is then required to allow the merging of the information contained in the two incomplete digital elevation models. Common control points are identified on both digital elevation models in order to compute a first adjustment. This adjustment is then refined by an optimization algorithm that minimizes the discrepancies between the two digital elevation models.

\subsection{Study field and rain erosivity measurement}

An experimental plot has been selected on a cultivated field to provide the soil sample for the validation of the molding method as well as to provide the real micro-topographies that will be molded for the study of depression storage and surface detention evolutions as a function of cumulative rainfall erosivity. This experimental plot is situated in the loess belt of central Belgium (Long. $4^{\circ} 38^{\prime} 41.631 \mathrm{E}$, Lat. $50^{\circ} 40^{\prime} 4.622 \mathrm{~N}$, elevation $136 \mathrm{~m}, 10 \%$ average slope), near the city of Louvain-la-Neuve. The soil is a silt loam (Haplic Luvisol; FAO et al. [1998]). At the begining of the experiment (11 March 2009), the soil of the field has been tilled and sowed with spring wheat using the following seedbed preparation tools: field cultivator, moldboard plow, spring tine cultivator and combined drill with rotary harrow and cage roller. Ten meter downstream the upper field border, an area of $3 \times 10 \mathrm{~m}^{2}$ (the long side of the rectangle is perpendicular to the mean slope) was kept bare, by spraying an herbicide on the young shoots of wheat. Nine molds $(0.5-\mathrm{m}$ wide and 1-m long in the slope direction) were taken at 4 different times between March 2009 to June 2009 , the first time beeing just after tillage. During that period, rainfall rate was measured with a tipping bucket rainfall gauge at $1-\mathrm{min}$. intervals with a $0.2-\mathrm{mm}$ resolution. Those measurements were converted to rain erosivity computed on 10-min. intervals, based on the methodology of Verstraeten et al. [2006]. Each of the nine molds were associated with a cumulative rain erosivity (R) expressed in MJ.ha $\mathrm{h}^{-1} \cdot \mathrm{an}^{-1} \cdot \mathrm{mm} \cdot \mathrm{h}^{-1}$. The following molds were taken: 2 molds on the 11th of March, just after tillage ( $\mathrm{R}=0), 2$ molds on the 20th of April $(\mathrm{R}=45), 3$ molds on the 18th of May $(\mathrm{R}=115)$ and 2 molds on the 29th of July $(\mathrm{R}=230)$. An additional mold was taken on an other field, where a seedbed preparation for sugar beet had been maid. The soil was kept bare and was exposed for more than 5 months to the rainfall, during spring and summer when most of the intensive thunderstorms occur. Based on visual inspection of the soil surface, we hypothesize that this last mold correponds to the final stage of soil micro-topography and subjectively associated it with a one year value of erosion in Belgium ( $\mathrm{R}=677$, Verstraeten et al. [2001]).

\subsection{Surface detention and depression storage measurements}

On the experimental plot, the different molds were taken parallel to the soil surface, and the remaining angles with the horizontal plan were measured. In laboratory, the corresponding casts were firstly submerged 12 hours in a water basin to reduce the infiltration of water despite the waterproof coating, then tilted to show the same respective slopes as in the field. The cast were also hydrologically isolated to avoid any escaping flows on the upper and the side boundaries. Runoff water was collected in a gutter at the downstream boundary of the cast. The runoff rate was determined by collecting the runoff during a determined interval of time and weighing the collected water.

Water supply $\mathrm{Q}$ was brought to the impermeable micro-topography following two ways: either through sprinkling over the entire surface $(\mathrm{Q}=$ rain), or as runon over the entire length of the upstream boundary $(\mathrm{Q}=$ runon). In our approach, we considered a mean effective height of water as well as a mean effective velocity in the direction of the main slope. As such, the whole cast is considered as an elementary surface representative of a single grid cell ( 1 meter long) in a hillslope model. We chose that option to give to modelers representative effective values of surface 
Version définitive du manuscrit publié dans / Final version of the manuscript published in :

Catena, 91, 10-20

detention and depression storage at the scale to which classical hillslope models perform. We also considered that the water in the depression storage did not contribute to the flow. Therefore, the detention storage was the only active layer and the velocity was computed by dividing the runoff rate by the surface detention (expressed in water depth) and by the width of the mold. Doing so, we conformed to classical concepts of hillslope models that separate surface detention and depression storage explicitly.

Maximum $D_{s}$ was directly measured by spraying a large amount of water onto the cast. We waited until no water flowed anymore at the downstream boundary. We sponged up the water in the depressions, weighed the water and the sponge and retrieved the weight of the sponge previously measured. Finally, the weight of water was transformed in a volume, and then we divided the volume by the area of the cast projected on the horizontal plane to express the depression storage in water depth units. The full operation is repeated 3 times, and the mean result was computed.

$S_{d}$ was assessed by making a runoff experiment on the cast with a constant water supply (rain or runon). We waited untill the runoff rate reaches the dynamic equilibrium, when surface detention and depression storage do not increase anymore. We measured the constant runoff rate downslope to determine the water supply upslope. After that this measurement was repeated three times, we stopped the water supply and started immediately to collect the runoff. Since no water was supplied anymore, the water flowing at the downstream boundary might come from the surface detention. When runoff ended, all the water of the surface detention had been recuperated. This amount of water was weighed, transformed in volume and divided by the area of the cast projected on the horizontal plane to express, finally, the surface detention in water depth units.

\section{Results and Discussion}

\subsection{Validation of the molding method}

In a first step to assess the quality of the cast, two forms were created: 1) a flat PVC form with three peaks and 2) a patterned PVC form. These forms and their plaster reproductions were measured with a laser scanner (Figure 2). This enables to check if distances (e.g. between two maxima) were correctly represented as well if no general distortion could appear during the drying or the pouring of the materials. In additions, the original profiles of the two forms were directly measured with an iron ruler and a caliper rule to show the noise linked to the laser measurement itself.

Visual inspection shows that horizontal lines stay mostly linear and the distances between maxima are preserved. Some discrepancies are observed between the profiles, but those are mostly below the resolution of the laser scanner $(0.5 \mathrm{~mm})$. Besides, some details less than $0.5 \mathrm{~mm}$ wide were perfectly reproduced.

In a second time, we scanned a real rough and wet soil sample, as well as its plaster reproduction. The digital elevation models of the soil surface and its plaster cast are shown in Figure 3 (a) and (b). Missing data in the digital elevation models, due to uncompensated shading effects during the scanning process, are left white. Missing data are usually in the neighborhood of clods that produce shadow effects. Those missing values can be estimated by interpolation procedures but in order to analyze the discrepancy between the different micro-topographies, they are not considered. Figure 3 (c) shows the difference between the plaster micro-topography and the soil micro-topography. The largest positive errors (which correspond to a higher topographical level on the reproduction than on the soil) are located in the upper-left corner and in the center-right, whereas negative errors are located in the lower-left and upper-right corners. They may be due to a small deformation of the alginate mold or plaster cast at the large scale. Those discrepancies remain mainly within the resolution of the laser: since we subtract two variables each having 0.5 $\mathrm{mm}$ uncertainty, the result has $1 \mathrm{~mm}$ uncertainty. Figure 4 shows the distribution of the error 
Version définitive du manuscrit publié dans / Final version of the manuscript published in :

Catena, 91, 10-20

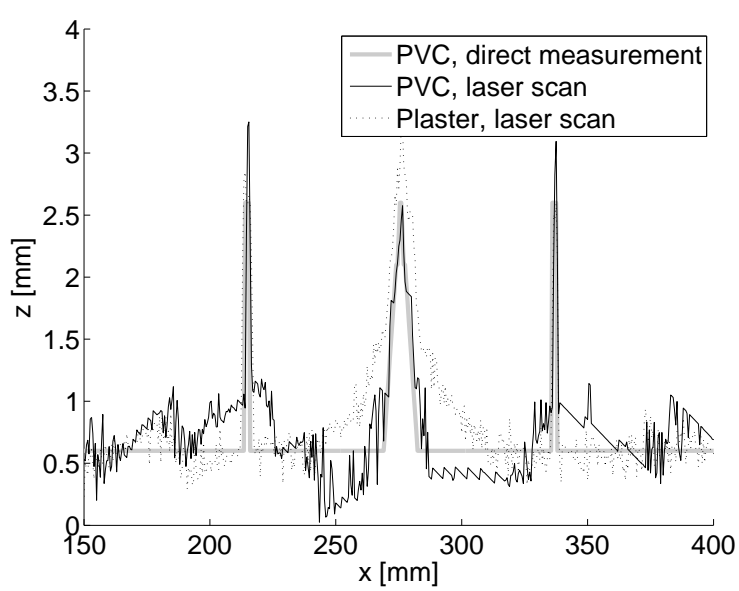

(a)

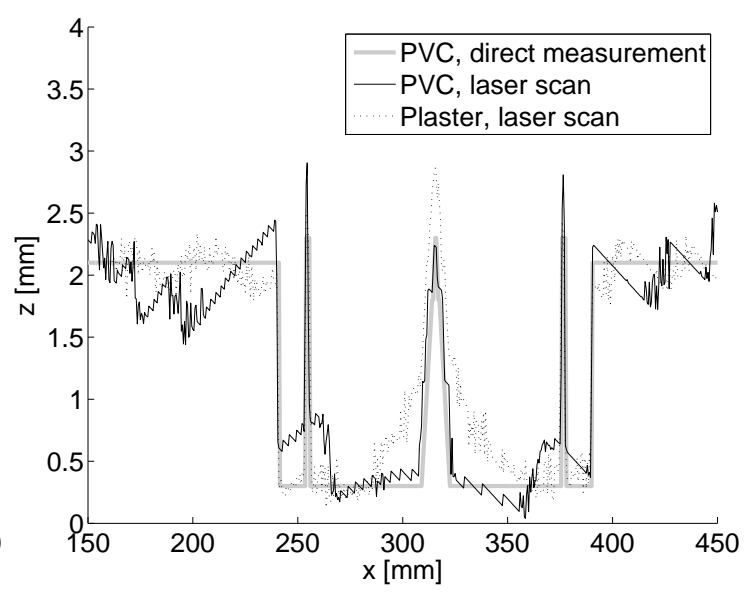

(b)

Figure 2: Comparison of 2-D profiles of a flat surface with 3 peaks (a) and a patterned PVC surface (b) with their plaster copies, measured manually and with the laser scanner.

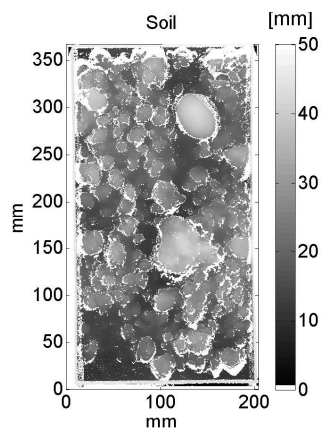

(a)

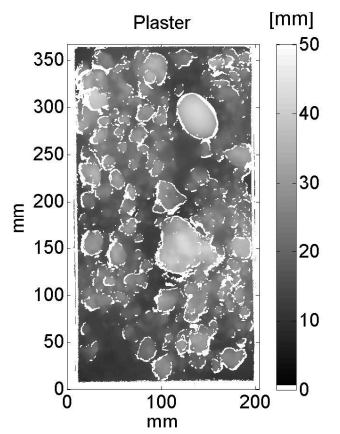

(b)

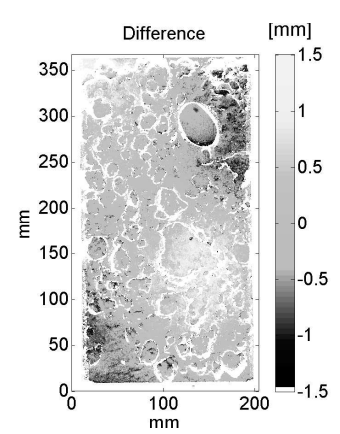

(c)

Figure 3: Digital elevation models of the soil (a), of the corresponding plaster reproduction (b), and the discrepancies between the two (c): $z_{\text {Plaster }}-z_{\text {Soil }}$. Missing data are left white.

which is almost symmetrical around the mean, indicating no bias and which is linked also to the registration procedure. The standard deviation $\sigma$ is $0.55 \mathrm{~mm}$, almost equivalent to the laser scanning resolution. Moreover, in their estimation of measurement precision, Darboux and Huang [2003, Fig. 7(b)] found a standard deviation of $0.39 \mathrm{~mm}$ when comparing two measurements of the same soil surface. The present standard deviation is only slightly larger while we are comparing a surface and its cast. To conclude, we can say that the proposed molding method allows to reproduce the soil micro-topography with a precision of at least $1 \mathrm{~mm}$, remembering that the largest errors may be due to a global deformation of the mold. However, since the observed precision is better than the resolution of the laser process, the reality of the systematic error due to the mold deformation may be questioned.

\subsection{Application of the molding method for assessing the depression storage evolu- tion}

The molding technique was applied to get the evolution of the soil surface topography of a loamy plot with time. Figure 5 (a) shows the evolution of the measured maximum depression storages 


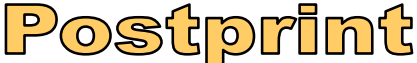

Version définitive du manuscrit publié dans / Final version of the manuscript published in :

Catena, 91, 10-20

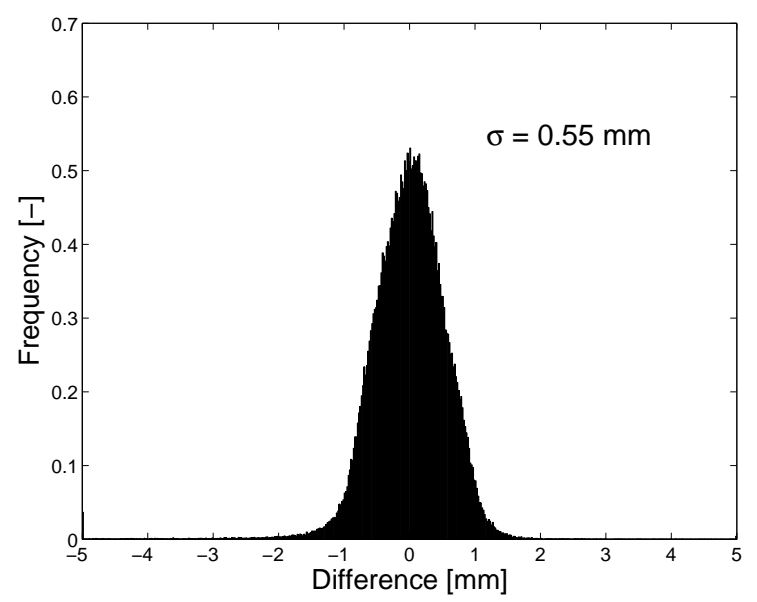

Figure 4: Distribution of the observed difference between the digital elevation models of the plaster reproduction and the original soil.

as a function of the cumulative rainfall erosivity $(\mathbf{R})$. As rain events occur, the micro-topography smooths, as a results of aggregates breakdown, erosion and deposition processes. We observe a general decrease of the maximum depression storage as $\mathrm{R}$ increases, except for the transition between $\mathrm{R}=0$ and $\mathrm{R}=45$. Our explanation is that, on the $\mathrm{R}=0$ molds, the soil aggregates produced by soil tillage had a small contact area with the soil at their bottom, leaving a lot of space for the water to flow under the clods. On the contrary, the aggregates on the $\mathrm{R}=45$ molds are more subsided and retain the water. The values of the depression storage are of the same order of magnitude as the data collected on eight different soils, during 2 years in northwestern Europe [Kamphorst et al., 2000b].

Figure 5 (b) shows the evolution of the Random Roughness (RR) as a function of the cumulative rainfall erosivity. Such as in the study of Kamphorst et al. [2000b], we compute RR as the standard deviation of heigth readings after correction of the slope, but without the log transformation. Except for the $\mathrm{R}=677$ mold that is clearly smoother than the others, the rest of the molds do not present a clear decreasing trend between RR and $\mathrm{R}$. This means that RR is not sensitive to the small changes in micro-topography that diminish the depression storage, such as the little incisions at the outlet of puddles. In a previous numerical study on connectivity properties of the micro-topography, we had shown that, for extrem cases, micro-topographies could present the same slope, the same RR and the same characteristic length, but have surface detention varying in a ratio 1 to 5 [Antoine et al., 2009].

To compare the direct measurement of depression storage with more classical indirect evaluations, we scanned all the microtopographies and used a filling algorithm (described in Antoine et al. [2009]) to determine the different depression storages. We computed also the maximum depression storages using the regression found by Kamphorst [2000a] that is based on the slope and the random roughness. Figure 6 shows the results of these indirect evaluations compared to our direct measurements. The filling algorithm methodology tend, in our case, to overestimates the maximum depression storages. We attibute the discrepancies to overhang problems: the upper side of the clods are represented in the digital elevation models, while, in reality, water can flow partially under the clods. We had even notice clods in arch shapes in some of our molds. The regression of Kamphorst [2000a], in our case, overestimates the maximum depression storage, but the results are still in the order of precision $(3 \mathrm{~mm})$ given by the authors. 


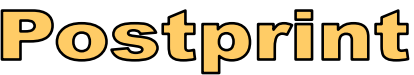

Version définitive du manuscrit publié dans / Final version of the manuscript published in :

Catena, 91, 10-20

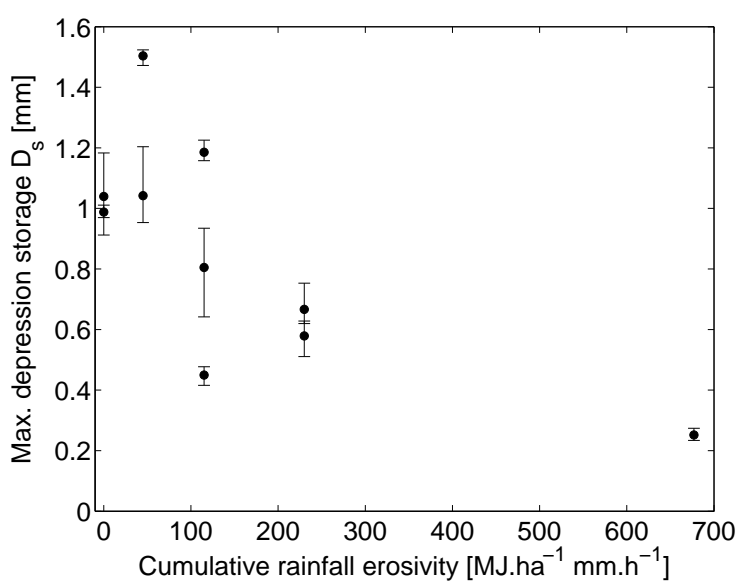

(a)

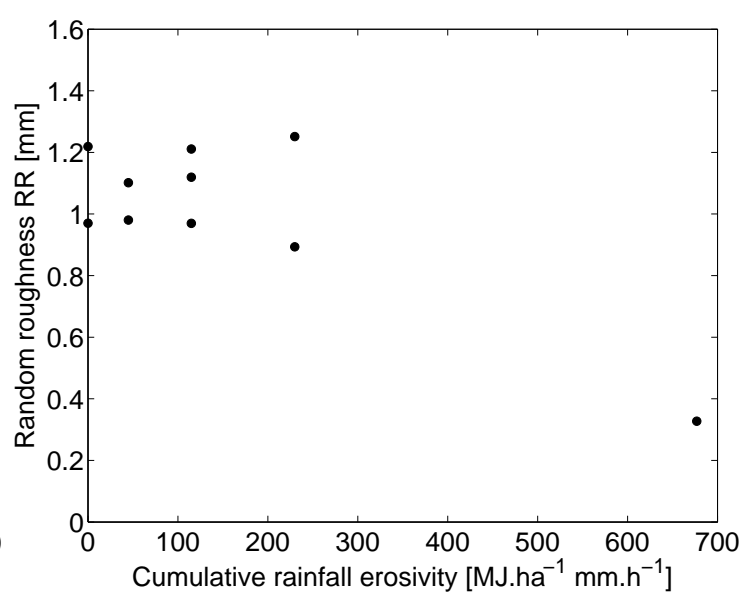

(b)

Figure 5: Evolutions of the maximum depression storage (a) and random roughness (b) as a function of cumulative rainfall erosivity.

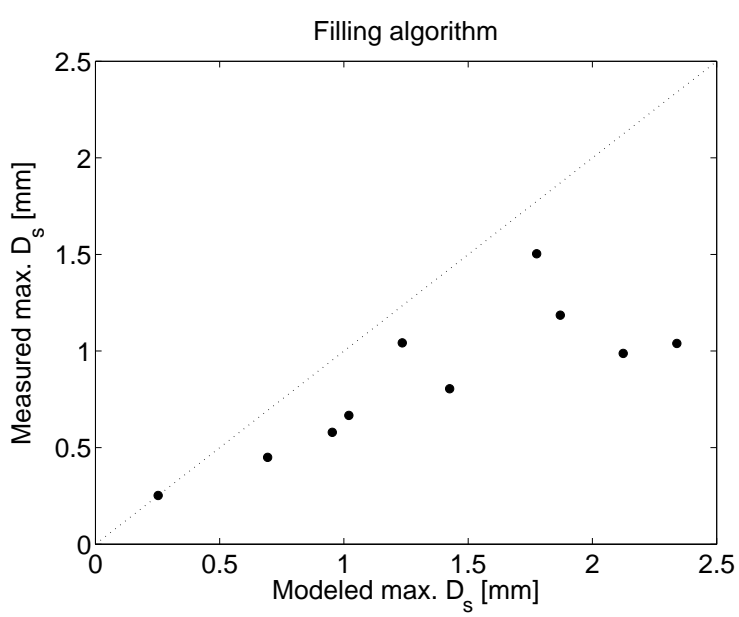

(a)

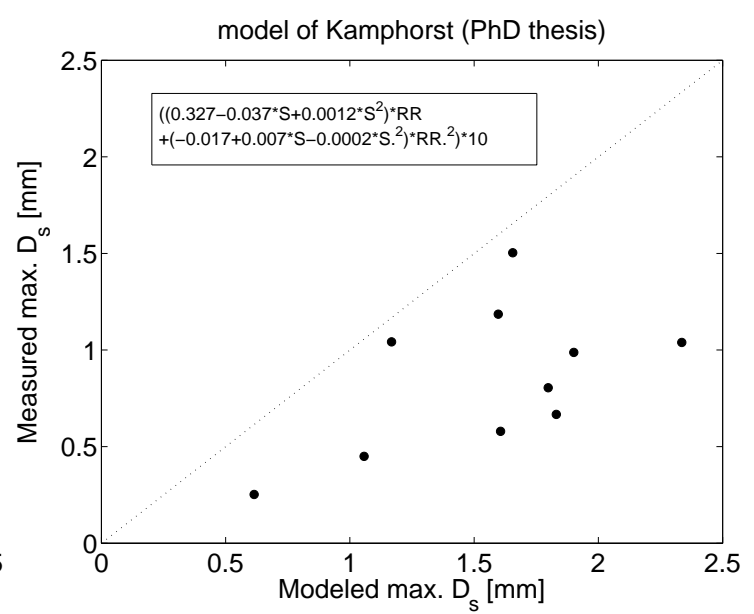

(b)

Figure 6: Indirect evaluations versus direct measurements of maximum depression storage: with a laser scanning and a filling algorithm (a) or with the regression of Kamphorst [2000a], knowing the slope $\mathrm{S}[\%]$ and the random roughness $\mathrm{RR}[\mathrm{m}]$. 
Version définitive du manuscrit publié dans / Final version of the manuscript published in :

Catena, 91, 10-20

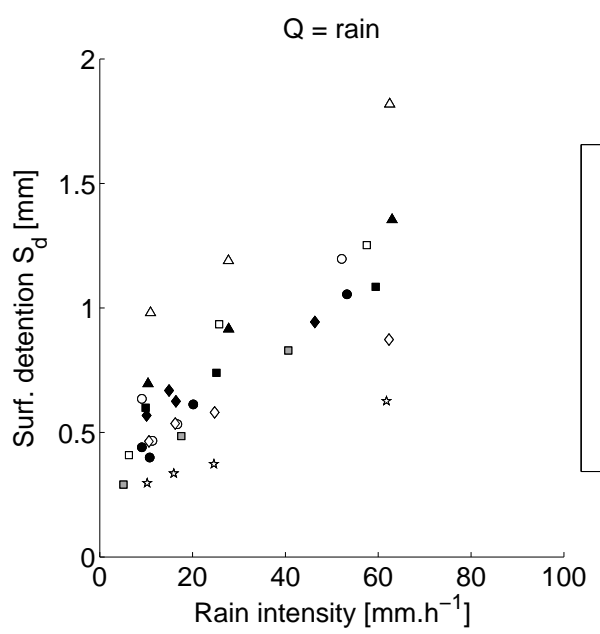

(a)

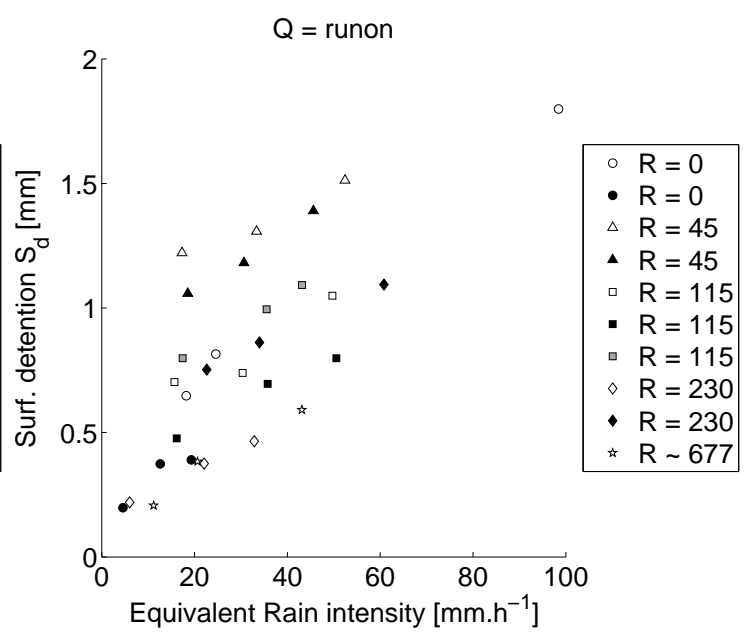

(b)

Figure 7: Surface detention as a function of the rain intensity: uniform rain (a) and runon (b). The runon flow rate has been divided by the mold surface in order to be expressed in the same unit as the rain supply. Experimental points from a common mold are represented by a same symbol. The molds are named according to their cumulative rainfall erosivity value.

\subsection{Application of the molding method for assessing surface detention evolution}

We present our experimental results in Figures 7 and 8. In each figure, the results are separated according to the way water is supplied: either through sprinkling over the entire surface $(\mathrm{Q}=$ rain), or as runon over the entire length of the upstream boundary $(\mathrm{Q}=$ runon). To better compare the two cases, we express the water supply in the same units (i.e. a rain intensity, or an equivalent rain intensity). Therefore, for the runon case, the upstream water supply expressed by a volumetric rate $\left[\mathrm{m}^{3} \cdot \mathrm{s}^{-1}\right]$ has been divided by the surface $\left[\mathrm{m}^{2}\right]$ of the mold. It is as if all the rain that would have fallen on the mold had been concentrated at the upstream boundary. Take note that for rainfed experiments, overland flow is present on the whole surface of the cast, while, for the runon experiments, overland flow occurs only along preferential paths.

The experimental relationship between the rain intensity and the surface detention is shown in Figure 7, for the different molds referred to by their respective $\mathrm{R}$ values. The $\mathrm{R}=45$ molds show generally a larger detention storage value than the others, for an equivalent rain intensity. On the contrary, the $\mathrm{R}=677$ mold has generally the lowest detention storage. We would expect that, with increasing $\mathrm{R}$ values, water moves with a higher velocity for a same discharge, decreasing the detention storage for an equivalent rain intensity. Therefore, it is surprising that the surface detentions of the $\mathrm{R}=0$ molds are not above or similar to the surface detentions of the $\mathrm{R}=45$ molds. It is explained by the fact that, as already mentioned in the discussion of depression storage, the micro-topography of the $\mathrm{R}=0$ molds do not exhibit any spatial organization. Overland flow does not really concentrated into channels but rather moves in a sheet flow around the obstacles. Moreover the soil at that time was like a loose porous material with small and weak contacts between aggregates, and water could easily flow around and below them. Flow paths were thus fairly straight. In contrary, the aggregates on the $\mathrm{R}=45$ molds have more subsided and force the water to flow around them, rendering the flow paths more tortuous.

The experimental relationship between the surface detention and the mean velocity in the direction of the main slope is shown in Figure 8. For each mold taken separately, the velocities increase with the surface detention values, and the relationship shows a decreasing positive slope. 
Version définitive du manuscrit publié dans / Final version of the manuscript published in :

Catena, 91, 10-20

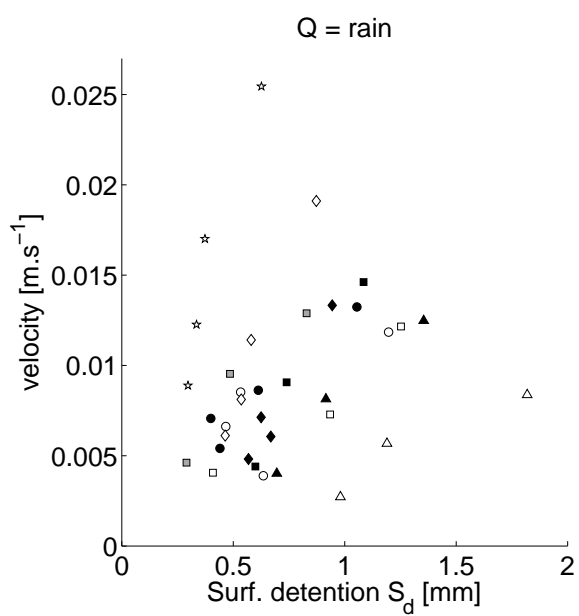

(a)

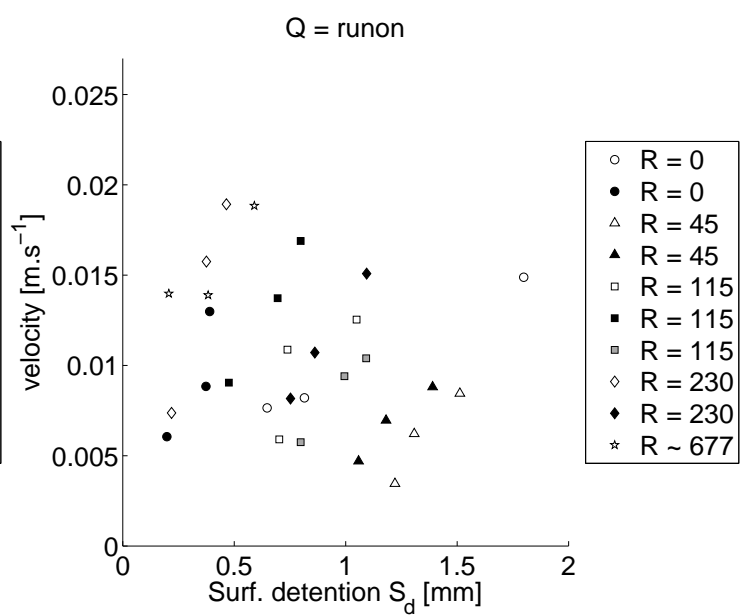

(b)

Figure 8: Effective velocity in the main slope direction as a function of the surface detention (or active layer depth): uniform rain (a) and runon (b). The runon flow rate has been divided by the mold surface in order to be expressed in the same unit as the rain supply. Experimental points from a common mold are represented by a same symbol. The molds are name according to their cumulative rainfall erosivity value.

The relationship is sharper for the $\mathrm{R}=677$ mold. An explanation is that the real directions of the flowpaths are mostly parallel to the main slope direction, so that the effective velocity tends to be the real velocity. On the other molds, the water follows more tortuous paths. The increase of the real velocity with the increase of water depth is thus mitigated, when projected to mean slope direction.

\subsection{Parametrization of the surface detention by an effective friction factor}

Due to experimental constraints, we could not ensure an identical slope for the different molds (4 to $10 \%$ ). This effect could blur some of the tendencies, and may explain partially the dispersion of the experimental data in the previous figures. In most of hillslope models of runoff and erosion, such as KINEROS [Woolhiser et al., 1990], WEPP [Flanagan and Nearing, 1995], LISEM [de Roo et al., 1998], EUROSEM [Morgan et al., 1994] or CREDHYS [Laloy and Bielders, 2008], microtopography is implicitely considered with a friction factor. Knowing the mean effective velocity, mean effective water depth and mean surface slope, we could estimate the effective friction factors for our molds. To summarize the information contained in the data, we plotted the experimental points into a log- log- Moody diagram (Figure 9). The Moody diagram expresses the DarcyWeisbach friction factor $\lambda[-]$ as a function of the Reynolds number $\operatorname{Re}=\frac{\bar{v} D}{\vartheta}=\frac{\bar{v} 4 R_{h}}{\vartheta}$, where $\bar{v}$ is the mean flow velocity along the global slope $\left[\mathrm{m} . \mathrm{s}^{-1}\right], D$ is a characteristic length that is four times the hydraulic radius $R_{h}[\mathrm{~m}]$ and $\vartheta$ is the kinematic viscosity $\left[\mathrm{m}^{2} . \mathrm{s}^{-1}\right]$. The hydraulic radius corresponds to the mean local water depth $\bar{h}[\mathrm{~m}]$, which is our surface detention value. The experimental lambda values were found by inverting the Darcy-Weisbach formulation and assuming a uniform flow [Chow et al., 1988]:

$$
S_{f}=S_{0}=\lambda \frac{1}{4 R_{h}} \frac{\bar{v}^{2}}{2 g}
$$


Version définitive du manuscrit publié dans / Final version of the manuscript published in :

Catena, 91, 10-20

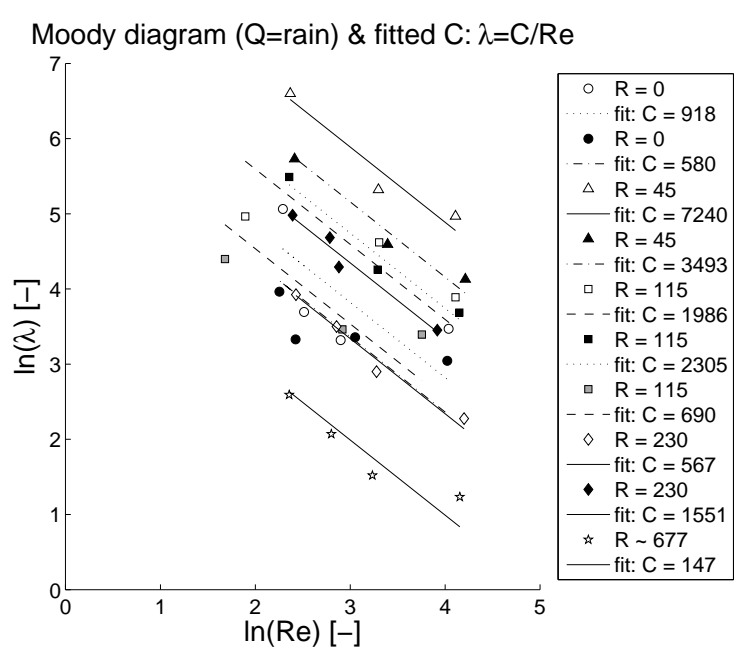

(a)

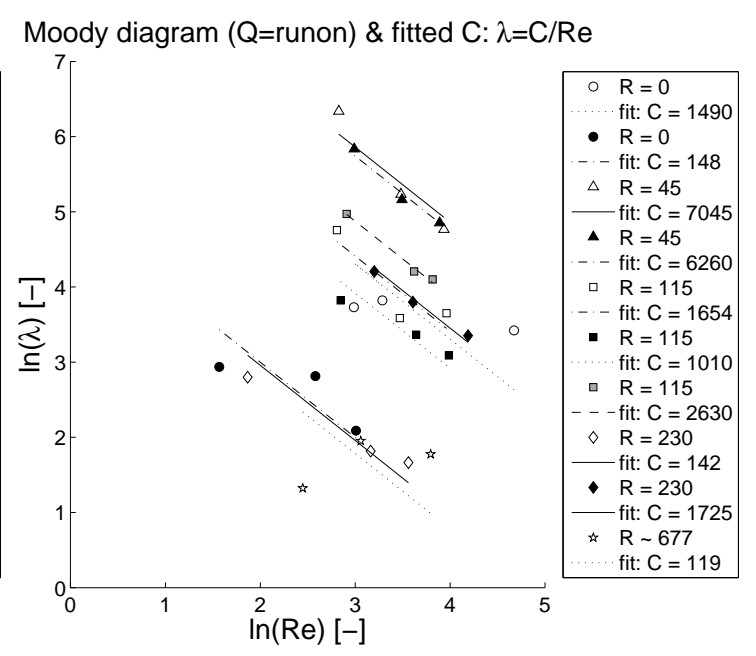

(b)

Figure 9: Log- log- Moody diagrams with the experimental data and the fitted linear relations. Experimental points from a common mold are represented by a same symbol. The molds are name according to their cumulative rainfall erosivity value.

where $g$ is the gravitational acceleration $\left[\mathrm{m} . \mathrm{s}^{-2}\right], S_{0}$ is the mean global slope of the soil and $S_{f}$ is the friction slope. In the opposite way, when we know $\lambda$, and assuming a uniform flow, we can find back the mean water depth equivalent to the surface detention, using the following equation [Chow et al., 1988]:

$$
\bar{h}=\left(\frac{\lambda q_{0}^{2}}{8 g S_{0}}\right)^{1 / 3}
$$

where $q_{0}\left[\mathrm{~m}^{2} . \mathrm{s}^{-1}\right]$ is the discharge per unit width and is equal to $\bar{v} \bar{h} . q_{0}$ can be found by dividing the runoff rate $\left[\mathrm{m}^{3} \cdot \mathrm{s}^{-1}\right]$ by the width of the mold $[\mathrm{m}]$.

All our experimental data are in the laminar domain (Re $\leq 2000)$. It is a result of computing a mean velocity and a mean water depth on the entire cast. In reality, flow filaments and backwater flows as described by Dunkerley [2003] coexist and turbulent flows occur locally next to laminar flows. For laminar flow, the friction factor is determined by [Chow et al., 1988]:

$$
\lambda=\frac{C}{\operatorname{Re}}
$$

where $C$ is a constant that is equal to 96 for a smooth surface and is larger if the surface is rough [Dunkerley, 2001]. Our micro-topographies are clearly rough, and the roughness is largely higher than the water depth itself, which forces the water to follow a tortuous path. The Darcy-Weisbach, Chézy and Manning equations are classically used in most of runoff and erosion models, although they originated from studies on one-dimensional pipe flows under very different conditions than those occurring with overland flow [Smith et al., 2007]. In Particular, the hypothesis of microroughness, that is the water covers all the soil surface, is not met. Therefore, the classical approaches have been criticized and new explaining factors such as the inundation ratio have been put forward [Lawrence, 1997, 2000; Takken and Govers, 2000; Roche et al., 2007]. However, in our experiments were water is supplied by the rain, the entire surface is subject to overland flow. We can therefore not compute any inundation ratio, excepted by defining arbitrarily a minimum level of water to distinguish what is part of the runoff network and what is not. Moreover, most of 
Version définitive du manuscrit publié dans / Final version of the manuscript published in :

Catena, 91, 10-20

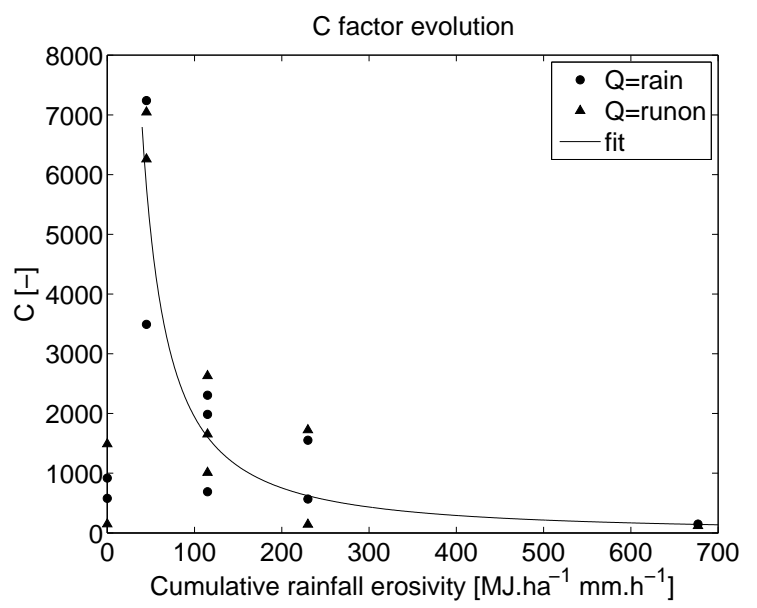

Figure 10: Evolution of the fitted $\mathrm{C}$ values with the accumulation of rainfall erosivity.

the hillslope models still work with elementary homogeneous grid cells [Singh, 1995; Singh and Frevert, 2002]. This explains why it is interesting to see if the simple classical equation 4 still holds in our case. Therefore, we fitted the $\mathrm{C}$ factor, by computing the following linear regression in the log- log- Moody diagram (Figure 9):

$$
\ln (\lambda)=-\ln (\operatorname{Re})+\ln (C)
$$

The fact that we impose a -1 slope in the relationship $\ln (\lambda)$ versus $\ln (\operatorname{Re})$ does not allow to model properly some data, such as for the $\mathrm{R}=0$ and $\mathrm{R}=677$ molds with an upstream supply. As opposed to the results of Dunkerley [2003], it is our smoothest soil $(\mathrm{R}=677)$ with an upstream water supply that showed a positive relationship between $\lambda$ and Re. Figure 10 shows the relationship between the fitted $C$ factor and the $\mathrm{R}$ value. The roughness of the soil evolves with the cumulative rainfall erosivity that tends to level out the soil surface and erode the obstructing elements. We note a general decrease of the $\mathrm{C}$ factor with $\mathrm{R}$ value, as the soil gets smoother, except at the beginning. As explained earlier about the $\mathrm{R}=0$ molds, we found a large number of interstices at the bottom of the clods through which the water was flowing easily. These interstices will generally disappear after the first runoff when the clods will begin to subside and stick to the soil at their bottom. Therefore the initial state will not be considered any further in this paper. In addition, a runoff experiment with a $100 \mathrm{~mm} / \mathrm{h}$ rain during 1 hour had not produced any significant runoff on the field were the micro-topographies were extracted at $\mathrm{R}=0$, making that state not relevant for runoff modeling.

Finally, excluding the data of the $\mathrm{R}=0$ data, we fitted a simple model of the type:

$$
C=a R^{b}
$$

where $a$ and $b$ are shape factors. In our case, the best results where $a=\exp (13.86)$ and $b=-1.37$. With this simple model, equation 3 turns into:

$$
\bar{h}=\left(\frac{a R^{b} \vartheta q_{0}}{32 g S_{0}}\right)^{1 / 3}
$$

This simple equation summarizes the effect of the rainfall erosivity $\mathrm{R}$ on the overland flow behavior. We applied this equation to model $\bar{h}$, and we modeled $\bar{v}$ by dividing $q_{0}$ by the modeled $\bar{h}$, for all our experimental points. Figure 11 shows the modeled values and the experimental 


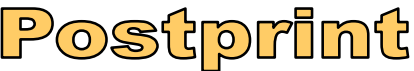

Version définitive du manuscrit publié dans / Final version of the manuscript published in :

Catena, 91, 10-20

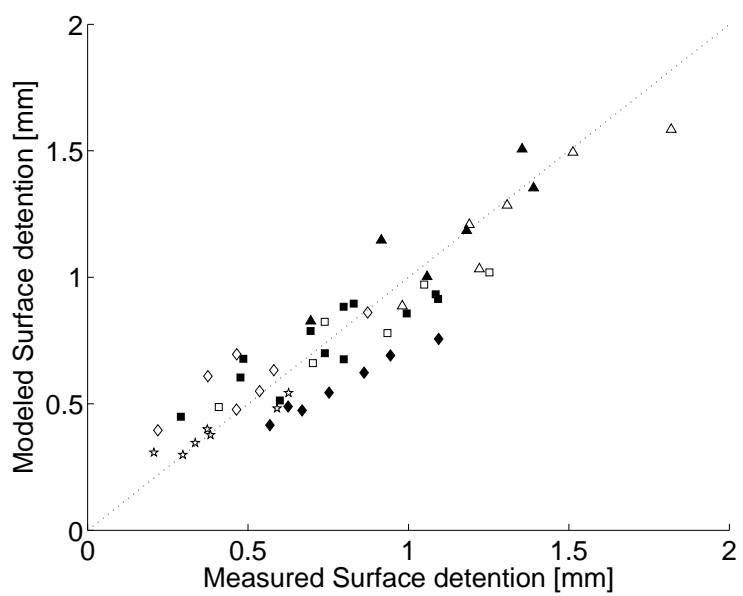

(a)

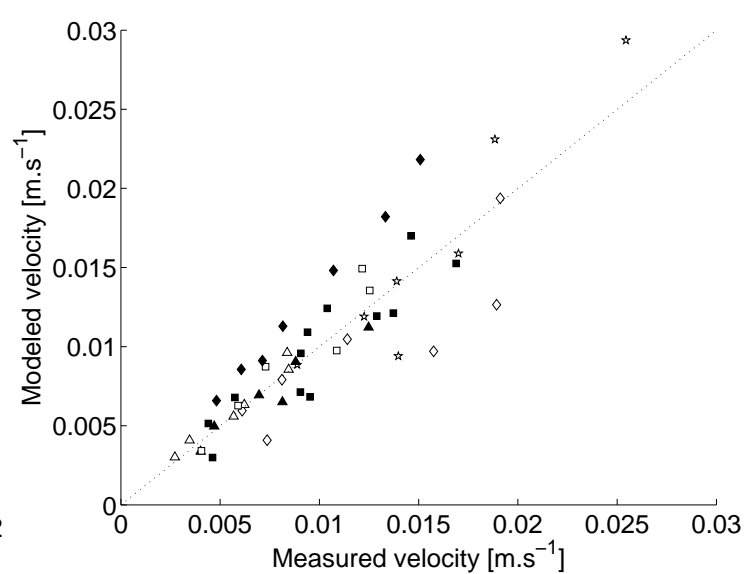

(b)

Figure 11: Comparison of the observed and modeled (Eq. 7) surface detention (a) and derived mean velocity (b) in the global slope direction.

measurements. The root mean square error (RMSE) are $0.2272 \mathrm{~mm}$ for $\bar{h}$ and $0.0037 \mathrm{~m} / \mathrm{s}$ for $\bar{v}$. In comparison, if we had ignored the non-stationarity of the value of $\mathrm{C}$ with time and thus had considered a unique mean value for $\mathrm{C}(\bar{C}=2085)$ for all our field by averaging all the different $\mathrm{C}$ values, the RMSE would have been $0.5896 \mathrm{~mm}$ for $\bar{h}$ and $0.0081 \mathrm{~m} / \mathrm{s}$ for $\bar{v}$.

In the context of thin flows on rough surfaces, two other equations are proposed to link the soil roughness to effective frictions factors. Gilley and Finkner [1991] proposed the following equation:

$$
\lambda=\frac{6.30(1000 R R)^{1.75}}{R e^{2 / 3}}
$$

where RR is the random roughness [m]. Smart et al. [2002] proposed the following equation:

$$
\lambda=\frac{8 R R}{\bar{h}}
$$

where $\bar{h}$ is the mean effective water depth [m]. Introducing equation 8 in equation 3 gives:

$$
\bar{h}=\left(\frac{0.3125(1000 R R)^{1.75} \vartheta^{2 / 3} q_{0}^{4 / 3}}{g S_{0}}\right)^{1 / 3}
$$

Introducing equation 9 in equation 3 gives:

$$
\bar{h}=\left(\frac{R R q_{0}^{2}}{g S_{0}}\right)^{1 / 4}
$$

We tested the two last equations for all our experimental points and compared the modeled and measured surface detentions and mean velocities. RMSE is $0.2991 \mathrm{~mm}$ for $\bar{h}$ and $0.0048 \mathrm{~m} / \mathrm{s}$ for $\bar{v}$ with the model of Gilley and Finkner [1991]. With the model of Smart et al. [2002], RMSE is $0.4827 \mathrm{~mm}$ for $\bar{h}$ and $0.0071 \mathrm{~m} / \mathrm{s}$ for $\bar{v}$.

This illustrates the fact that simple models may provide relatively good approximations of complex processes, and could constitute practical tools for modelers to define the order of magnitude of effective parameters at scales larger than the scales where real processes occur. Still, we acknowledge that the values of the surface detention, for the thin flow observed in interill, are small compare to the water depth that generally infiltrate. It is true that the estimation of the infiltration remains the main error source in the storage equation 1. 
Version définitive du manuscrit publié dans / Final version of the manuscript published in :

Catena, 91, 10-20

\section{Conclusions}

We developed a cheap and fast molding method based on alginic acid and plaster that is able to reproduce real soil surface micro-topography within at least $1 \mathrm{~mm}$ of precision. The molds are almost impermeable and allow to measure directly the surface detention and the maximum depression storage. Those two properties were shown to generally decrease with the accumulation of rain erosivity. The experimental measurements of surface detention were useful to validate the modeling of the effective friction forces and the resulting effective velocities at the meter scale. We proposed a simple model to determine, for the laminar domain, the evolution of the friction factor with the rain erosivity.

Our cheap molding technique already provides important metrics to be integrated in hillslope runoff-erosion models. In the future, it could allow one to create a collection of microtopographical reproductions, in order to study the combined actions of the rain and the agriculture practices on the micro-topographical properties. Moreover, molds are possible to make on vegetated fields, if stems are sufficiently robust to remain in their position when pouring the alginate onto the soil and width enough to be reproduced in the plaster cast (e.g. mature maize crop). Under laboratory conditions, the spatial variation of water velocity could be studied on the artificial micro-topographies to better model the erosion-deposition processes.

\section{References}

Abedini, M. J., W. T. Dickinson, and R. P. Rudra, On depressional storages: The effect of dem spatial resolution, Journal Of Hydrology, 318, 138-150, 2006.

Antoine, M., M. Javaux, and C. Bielders, What indicators can capture runoff-relevant connectivity properties of the micro-topography at the plot scale?, Advances In Water Resources, 32, 1297-1310, 2009.

Chahinian, N., R. Moussa, P. Andrieux, and M. Voltz, Accounting for temporal variation in soil hydrological properties when simulating surface runoff on tilled plots, Journal Of Hydrology, 326, 135-152, 2006.

Chow, V. T., D. R. Maidment, and L. W. Mays, Applied Hydrology, McGraw-Hill Publishing Co., 1988.

Darboux, F., and C. Huang, An instantaneous-profile laser scanner to measure soil surface microtopography, Soil Science Society Of America Journal, 67, 92-99, 2003.

Darboux, F., P. Davy, C. Gascuel-Odoux, and C. Huang, Evolution of soil surface roughness and flowpath connectivity in overland flow experiments, Catena, 46, 125-139, 2002.

de Roo, A., V. Jetten, C. Wesseling, and C. Ritsema, Modeling soil erosion by water, NATO ASI Series I. LISEM: a physically-based hydrologic and soil erosion catchment model., chap. vol. 55. (Chapter 32), pp. 430-440, 1998.

Dunkerley, D., Estimating the mean speed of laminar overland flow using dye injection-uncertainty on rough surfaces, Earth Surface Processes and Landforms, 26, 363-374, 2001.

Dunkerley, D. L., Determining friction coefficients for interrill flows: the significance of flow filaments and backwater effects, Earth Surface Processes and Landforms, 28, 475-491, 2003.

Elbasit, M. A. M. A., H. Anyoji, H. Yasuda, and S. Yamamoto, Potential of low cost close-range photogrammetry system in soil microtopography quantification., Hydrological Processes, 23, 1408-1417, 2009.

Esteves, M., X. Faucher, S. Galle, and M. Vauclin, Overland flow and infiltration modelling for small plots during unsteady rain: numerical results versus observed values, Journal of Hydrology, 228, 265-282, 2000.

FAO, ISRIC, and ISSS., World Reference Base for Soil Resources, World Soil Resources Report 84., FAO, Rome., 1998.

Favis-Mortlock, D., A self-organizing dynamic systems approach to the simulation of rill initiation and development on hillslopes, Computers \& Geosciences, 24, 353-372, 1998.

Flanagan, D., and M. Nearing, Usda-water erosion prediction project: hillslope profile and watershed model documentation. nserl report 10., Tech. rep., USDA-ARS National Soil Erosion Research Laboratory, West Lafayette, Indiana 47907., 1995.

Garcia-Sanchez, L., Modelisation de la dynamique ruissellement-infiltration en fonction des etats de surface, Ph.D. thesis, Universite Montpellier II, 1997.

Gayle, G. A., and R. W. Skaggs, Surface storage on bedded cultivated lands, Transactions Of The Asae, 21, 101-\&, 1978. 
Version définitive du manuscrit publié dans / Final version of the manuscript published in :

Catena, 91, 10-20

Gilley, J. E., and S. C. Finkner, Hydraulic roughness coefficients as affected by random roughness, Transactions Of The Asae, 34, 897-903, 1991.

Guzha, A. C., Effects of tillage on soil microrelief, surface depression storage and soil water storage, Soil \& Tillage Research, 76, 105-114, 2004.

Henderson, F. M., Open Channel Flow (Macmillan Series in Civil Engineering), Prentice Hall, 1966.

Jester, W., and A. Klik, Soil surface roughness measurement - methods, applicability, and surface representation, Catena, 64, 174-192, 2005.

Kamphorst, E. C., Mesures et méthodes d'estimation de la capacité de stockage d'eau dans le micro-relief créé par les opérations de travail du sol, Ph.D. thesis, Institut National Agronomique Paris-Grignon, 2000a.

Kamphorst, E. C., and Y. Duval, Validation of a numerical method to quantify depression storage by direct measurements on moulded surfaces, Catena, 43, 1-14, 2001.

Kamphorst, E. C., V. Jetten, J. Guerif, J. Pitkanen, B. V. Iversen, J. T. Douglas, and A. Paz, Predicting depressional storage from soil surface roughness, Soil Science Society of America Journal, 64, 1749-1758, 2000b.

Laloy, E., and C. L. Bielders, Plot scale continuous modelling of runoff in a maize cropping system with dynamic soil, surface properties, Journal Of Hydrology, 349, 455-469, 2008.

Lawrence, D. S. L., Macroscale surface roughness and frictional resistance in overland flow, Earth Surface Processes And Landforms, 22, 365-382, 1997.

Lawrence, D. S. L., Hydraulic resistance in overland flow during partial and marginal surface inundation: Experimental observations and modeling, Water Resources Research, 36, 2381-2393, 2000.

Martin, Y., C. Valeo, and M. Tait, Centimetre-scale digital representations of terrain and impacts on depression storage and runoff, Catena, 75, 223-233, 2008.

Morgan, R. P. C., J. N. Quinton, and R. J. Rickson, Modeling methodology for soil-erosion assessment and soil conservation design - the eurosem approach, Outlook On Agriculture, 23, 5-9, 1994.

Paz-Ferreiro, J., I. Bertol, and E. V. Vazquez, Quantification of tillage, plant cover, and cumulative rainfall effects on soil surface microrelief by statistical, geostatistical and fractal indices, Nonlinear Processes In Geophysics, 15, 575-590, 2008.

Planchon, O., and F. Darboux, A fast, simple and versatile algorithm to fill the depressions of digital elevation models, Catena, 46, 159-176, 2002.

Roche, N., J. F. Daian, and D. S. L. Lawrence, Hydraulic modeling of runoff over a rough surface under partial inundation., Water Resources Research, 43, W08,410, 2007.

Singh, V. P., Computer models of watershed hydrology., Computer models of watershed hydrology., pp. xiv +1130 pp., 1995.

Singh, V. P., and D. Frevert, Mathematical models of small watershed hydrology and applications., Mathematical models of small watershed hydrology and applications, pp. xxi + 950 pp., 2002.

Smart, G. M., M. J. Duncan, and J. M. Walsh, Relatively rough flow resistance equations, Journal Of Hydraulic Engineering-Asce, 128, 568-578, 2002.

Smith, M. W., N. J. Cox, and L. J. Bracken, Applying flow restistance equations to overland flows, Progress In Physical Geography, 31, 363-387, 2007.

Stammers, W. N., and H. D. Ayers, The effect of slope and microtopography on depression storage and surface detention, General Assembly of Toronto, 3, 89-93, 1957.

Takken, I., and G. Govers, Hydraulics of interrill overland flow on rough, bare soil surfaces, Earth Surface Processes and Landforms, 25, 1387-1402, 2000.

Tatard, L., O. Planchon, J. Wainwright, G. Nord, D. Favis-Mortlock, N. Silvera, O. Ribolzi, M. Esteves, and C. H. Huang, Measurement and modelling of high-resolution flow-velocity data under simulated rainfall on a low-slope sandy soil, Journal Of Hydrology, 348, 1-12, 2008.

Verstraeten, G., K. Van Oost, A. Van Rompaey, J. Poesen, and G. Govers, Integraal land- en waterbeheer in landelijke gebieden met het oog op het beperken van bodemverlies en modderoverlast (proefproject gemeente gingelom), Tech. rep., Laboratorium voor Experimentele Geomorfologie, Afdeling Fysische en Regionale Geografie, Universiteit KULeuven, Leuven, Belgium., 2001.

Verstraeten, G., J. Poesen, G. Demaree, and C. Salles, Long-term (105 years) variability in rain erosivity as derived from 10-min rainfall depth data for ukkel (brussels, belgium): implications for assessing soil erosion rates, Journal of Geophysical Research-Part D-Atmospheres, pp. D22,109-1-11, 2006.

Woolhiser, D., R. Smith, and D. Goodrich, Kineros, a kinematic runoff and erosion model: documentation and user manual., Tech. rep., USDA, Agricultural Research Service, 1990. 